\title{
A new Robertsonian translocation in Blonde d'Aquitaine cattle, $\operatorname{rob}(4 ; 10)$
}

\author{
I Bahri-Darwich ${ }^{1}$, EP Cribiu ${ }^{1 *}$, HM Berland ${ }^{2}$, R Darré ${ }^{2}$ \\ 1 INRA, Laboratoire de Génétique Biochimique et de Cytogénétique, \\ Centre de Recherches de Jouy-en-Josas, 78350 Jouy-en-Josas Cedex; \\ 2 École Nationale Vétérinaire de Toulouse, \\ URA-INRA de Cytogénétique des Populations, \\ 23, Chemin des Capelles, 31076 Toulouse Cedex, France
}

(Received 22 February 1993; accepted 1 July 1993)

\begin{abstract}
Summary - The cytogenetic study of a population of Blonde d'Aquitaine cattle revealed the presence of a Robertsonian translocation. The chromosomes involved in this abnormality were determined using G (GTG), R (RBG) and C (CBG) banding techniques. The chromosomes in question were identified as chromosomes 4 and 10. The existence of 2 paternal half-sisters carrying the abnormality suggests that it originates from the sire.

cattle / chromosome / Robertsonian translocation

Résumé - Une nouvelle translocation chez les bovins Blonde d'Aquitaine, rob(4;10). L'étude cytogénétique d'une population de bovins Blonde d'Aquitaine a permis de trouver une nouvelle translocation robertsonienne. Les chromosomes impliqués dans cette anomalie ont été déterminés à l'aide des techniques de marquage $G(G T G), R(R B G)$ et $C(C B G)$. Les chromosomes concernés sont le 4 et le 10. L'existence de deux vaches porteuses demisœurs de père indique une origine vraisemblablement paternelle de l'anomalie.
\end{abstract}

bovin / chromosome / translocation robertsonienne

\section{INTRODUCTION}

Robertsonian translocations are the most commonly reported chromosome anomalies in cattle; the most widespread is the $1 ; 29$ translocation detected for the first time by Gustavsson and Rockborn (1964), and reported later with high frequency in numerous breeds worldwide (Popescu, 1977; Popescu and Pech, 1991). The $1 ; 29$ translocation is widespread in the Blonde d'Aquitaine breed since the frequency of the heterozygous and homozygous carriers ranges from 14 to $24 \%$ (Queinnec et

\footnotetext{
* Correspondence and reprints
} 
al, 1974; Cribiu, 1985; Frebling et al, 1987). In contrast, as in other breeds, other Robertsonian translocations have been reported only as sporadic cases (Berland et al, 1988; Cribiu et al, 1989). The present report describes a new Robertsonian translocation observed in Blonde d'Aquitaine cattle.

\section{MATERIALS AND METHODS}

\section{Animals}

Karyotypes were prepared from one phenotypically normal Blonde d'Aquitaine cow carrying the new translocation (the proband), its mother and 3 half-sisters (1 maternal half-sister and 2 paternal half-sisters), belonging to private farms near Toulouse, southwest France. The pedigree is shown in figure 1.

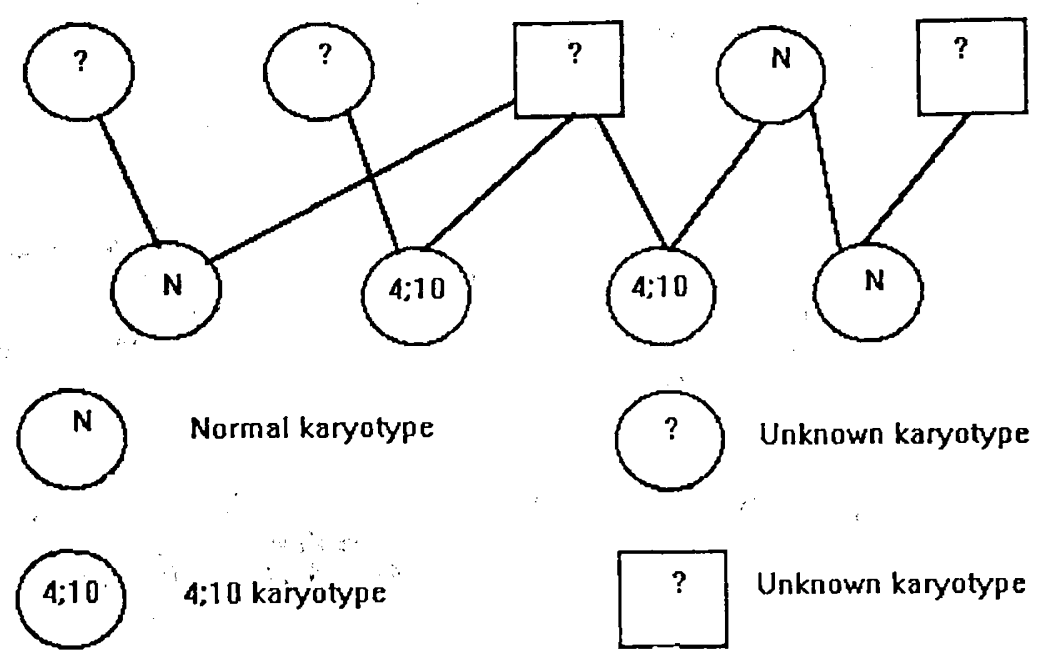

Fig 1. Pedigree showing the inheritance of the $4 ; 10$ Robertsonian translocation.

\section{Methods}

The karyotype of each cow was determined using whole blood cultures (Grouchy et al, 1964) and primary skin cell cultures (Chaffaux et al, 1986). The peripheral blood was cultured at $37^{\circ} \mathrm{C}$ for $72 \mathrm{~h}$ in Ham's F12 medium supplemented with $20 \%$ fetal bovine serum, $2 \mathrm{mM}$ glutamine, $100 \mu \mathrm{g} / \mathrm{ml}$ streptomycin and concanavalin A (final concentration: $0.1 \mu \mathrm{g} / \mathrm{l}$ ). Colcemid (final concentration: $0.03 \mathrm{mg} / \mathrm{l}$ ) was added to the culture $60 \mathrm{~min}$ before harvesting. Tissue biopsies were performed under local anesthesia on the rump. Primary fibroblast cultures were initiated from skin fragments, disrupted and digested in a trypsin solution $(2.5 \mathrm{~g} / \mathrm{l})$ and grown 
in a $\mathrm{CO}_{2}$ incubator as monolayer cultures in Falcon dishes $\left(75 \mathrm{~cm}^{2}\right)$ containing a medium similar to that previously described for lymphocyte cultures.

G-banding was achieved using a modification of the technique of Seabright (1971). The C-bands were obtained by the barium hydroxide/saline/Giemsa (BSG) technique (Summer, 1972). To induce R-banding, 5-bromo-2-deoxyuridine was added to the medium at a final concentration of 10 or $20 \mu \mathrm{g} / \mathrm{ml}$. The cultures were incubated at $37^{\circ} \mathrm{C}$ until the number of mitotic round cells reached a maximum, about 8 to $9 \mathrm{~h}$ after BrdU addition (Hayes et al, 1991). In order to obtain RBGbands, the cells were treated according to the procedure described by Hayes et al (1991) and fluorochrome-photolysis-Giemsa (FPG) staining was performed as described by Viegas-Péquignot et al (1989).

The chromosomes were identified, paired and arranged according to the recommendations of the Reading Conference (1976) and the ISCNDA (1989).

\section{RESULTS}

In classically stained metaphases, the karyotypes of the cow and 1 paternal halfsister included 59 chromosomes: the $2 \mathrm{X}$ chromosomes, 56 acrocentric and one large submetacentric chromosome. The G- and R-bands showed that chromosome pairs 4 and 10 are involved in the translocation (figs 2,3 ). The $\mathrm{C}$-banding

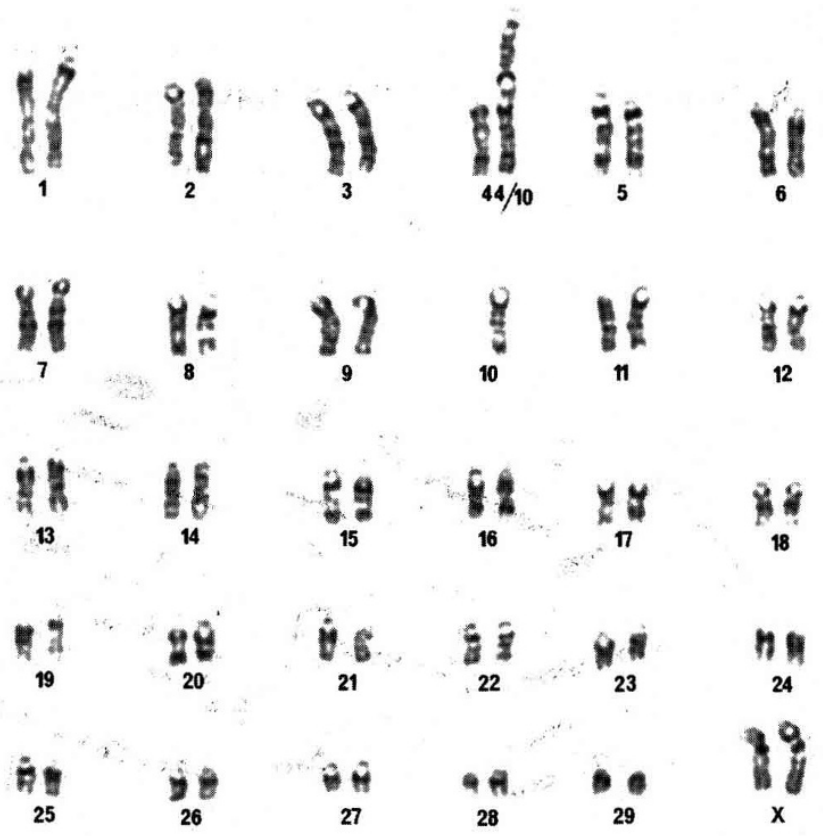

Fig 2. GTG-banded karyotype with the $4 ; 10$ translocation. 


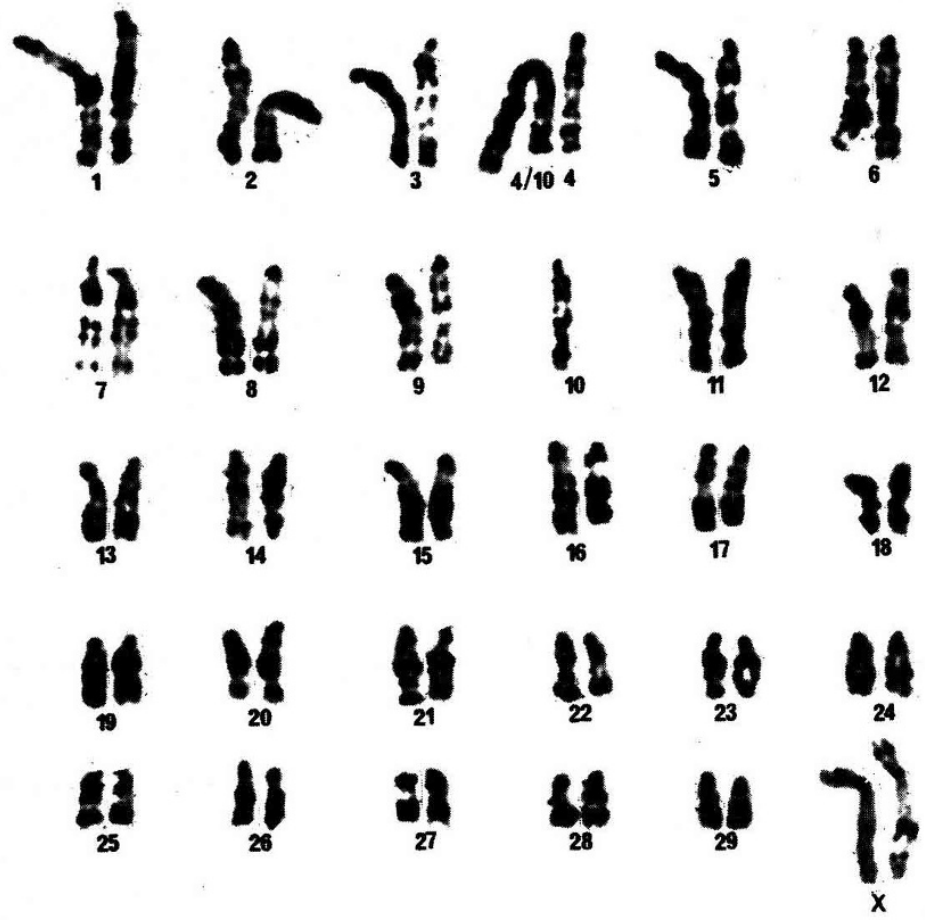

Fig 3. RBG-banded karyotype with the $4 ; 10$ Robertsonian translocation.

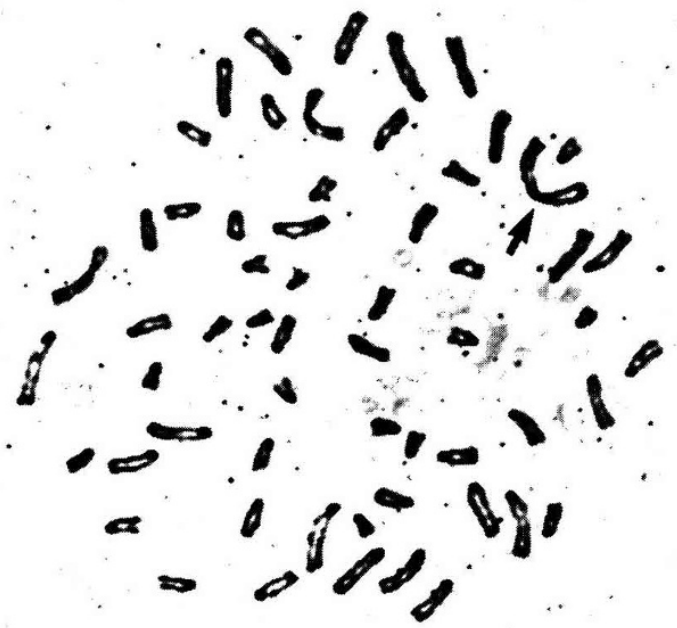

Fig 4. CBG-banded metaphase showing constitutive heterochromatin as 2 blocks in the $4 ; 10$ translocation (arrow). 
technique revealed the presence of 2 constitutive heterochromatin blocks in the pericentromeric region of the $4 ; 10$ translocated chromosome (fig 4).

Among the other 3 animals examined, the mother, 1 paternal half-sister and 1 maternal half-sister were normal with a diploid chromosome number $(2 n)$ of 60 .

\section{DISCUSSION AND CONCLUSION}

This chromosome abnormality is the fourth Robertsonian translocation reported in the Blonde d'Aquitaine breed. The first translocation was the $1 ; 29$ translocation which is known to have a wide distribution among AI bulls (Queinnec et al, 1974) and heifers (Frebling et al, 1987). Chromosomes implicated in the second and third translocations were identified as the 21 and 27, and the 9 and 23, respectively (Berland et al, 1988, Cribiu et al, 1989). These $2 \operatorname{rob}(21 ; 27)$ and $\operatorname{rob}(9 ; 23)$ have been observed only in one Blonde d'Aquitaine) bull and its progeny respectively.

Robertsonian translocations are the result of the fusion of 2 acrocentric chromosomes. Two types of Robertsonian translocations have been described in the Blond d'Aquitaine breed, depending on the presence of one block $(1 ; 29$ translocation $)$ and 2 blocks $(21 ; 27$ and $9 ; 23$ translocation $)$ of juxtacentromeric constitutive heterochromatin revealed by the CBG-banding technique (Berland et al, 1988; Cribiu et al, 1989). The presence of these 2 blocks would suggest the mechanism by which this translocation arose. The breakpoints involved the short arms, which are extremely limited in size, of both chromosomes 4 and 10 in the centromeric region; the fusion gave rise to a submetacentric chromosome and 2 minute fragments (short arms) which were lost during the subsequent cell divisions (Eldridge, 1974).

The origin of the translocation is uncertain, since the karyotype of the sire is unknown. It is probable that the $4 ; 10$ translocation originated from the sire since it was found in 1 paternal half-sister and not in the mother and the maternal half-sister.

As with a majority of Robertsonian translocations found in animal populations, the $4 ; 10$ translocation does not seem to be associated with phenotypic characteristics. In the absence of fertility records, a reduced fecundity in heterozygotes resulting from anaphase I nondisjunction and/or changes in the pattern of recombination in such individuals, cannot be excluded. For example, the $1 ; 29$ translocation produces in certain breeds a reduced fertility in the daughters of carrier bulls (Gustavsson 1969; Refsdal 1976).

\section{ACKNOWLEDGMENTS}

The assistance of G Fabre and his technical staff in the housing and handling of the animals at the Domaine Expérimental de Carmaux (INRA) is gratefully acknowledged. We thank $\mathrm{H}$ Hayes for her advice and help in chromosomal analysis (INRA, Laboratoire de Génétique Biochimique et de Cytogénétique). 


\section{REFERENCES}

Berland HM, Sharma A; Cribiu EP, Darré R, Bosher J, Popescu CP (1988) A new case of Robertsonian translocation in cattle. J Hered 79, 33-36

Chaffaux S, Cribiu EP, Crespeau F (1986) Un cas rare d'hermaphrodisme vrai latéral chez une chienne 78, XY. Rec Méd Vét 162, 463-470

Cribiu EP (1985) Fréquence de la translocation 1/29 dans les centres d'insémination artificielle français. Elev insémin 209, 17-22

Cribiu EP, Matejka M, Darré R, Durand V, Berland HM, Bouvet A (1989) Identification of chromosomes involved in a Robertsonian translocation in cattle. Genet Sel Evol 21, 555-560

Eldridge FEA (1974) A dicentric Robertsonian translocation in a Dexter cow. $J$ Hered 65, 353-355

Frebling J, Foulley JL, Berland HM, Popescu CP, Cribiu EP, Darré R (1987) Résultats de l'enquête sur la fréquence de la translocation $1 / 29$ en race bovine Blonde d'Aquitaine. Bull Tech. CRZV Theix INRA 67, 49-58

Grouchy de J, Roubin M, Passage E (1964) Microtechnique pour l'étude des chromosomes humains à partir d'une culture de lymphocytes sanguins. Ann Génét 7,45

Gustavsson I, Rockborn G (1964) Chromosome abnormality in three cases of lymphatic leukemia in cattle. Nature (Lond) 203, 990

Gustavsson I (1969) Cytogenetics, distribution and phenotypic effects of a translocation in Swedish cattle. Hereditas 63, 68-169

Hayes H, Petit E, Dutrillaux B (1991) Comparison of RBG-banded Karyotypes of cattle, sheep and goat. Cytogenet Cell Genet 57, 51-55

ISCNDA (1989) International System for Cytogenetic Nomenclature of Domestic Animals (Di Berardino D, Hayes H, Fries H, Long S, eds) Cytogenet Cell Genet 53, 65-79 (1990)

Popescu CP (1977) Les anomalies chromosomiques des bovins (Bos taurus L). État actuel des connaissances Ann Génét Sél Anim 9, 463-470

Popescu CP, Pech A (1991) Une bibliographie sur la translocation 1/29 des bovins dans le monde (1964-1990). Ann Zootech 40, 271-305

Queinnec C, Darré R, Berland HM, Raynaud JC (1974) Étude de la translocation 1/29 dans la population bovine du Sud-Ouest de la France : conséquences zootechniques. In: $1^{\mathrm{er}}$ Congrès Mondial de Génétique Appliquée à l'Elevage Animal. Madrid, 7-11 octobre; Garsi, Madrid, 131-151

Reading Conference (1976) Proceedings of the First International Conference for the Standardization of Banded Karyotypes of Domestic Animals, Reading, August 2-6, 1976 (Ford CE, Pollock DL, Gustavsson I, eds) Hereditas 92, 145-162 (1980) Refsdal AO (1976) Low fertility in daughters of bulls with $1 / 29$ translocation. Acta Vet Scand 17, 190-195

Seabright M (1971) A rapid banding technique for human chromosomes. Lancet 2, 971-972

Summer AT (1972) A simple technique for demonstrating centromeric heterochromatin. Exp Cell Res 75, 304-306 
Viégas-Péquignot E, Dutrillaux B., Magdelenat H, Coppey-Moisan M (1989) Mapping of single copy DNA sequences on human chromosomes by in situ hybridization with biotinylated probes: enhancement of detection sensitivity by intensified fluorescence digital-imaging microscopy. Proc Natl Acad Sci, USA 86, 582-586 